\title{
MENINGKATKAN DISIPLIN ANAK USIA DINI MELALUI KEGIATAN PARENTING DI KOBER AL- AQWAM KECAMATAN PAMEUNGPEUK
}

\author{
Rika Kurniati
}

IKIP Siliwangi

rikaresvia@gmail.com

\begin{abstract}
ABSTRAK
Merujuk pada permasalahan yang ada yaitu kurangnya kedisiplinan anak, peneliti mencoba mencari solusinya, yaitu melalui kegiatan parenting. Penelitian ini bertujuan : 1. Untuk mendeskripsikan perencanaan Meningkatkan Disiplin Anak Usia Dini Melalui Kegiatan Parenting di Kober Al- Aqwam Kecamatan Pameungpeuk. 2, Untuk mengetahui proses penyelenggaraan kegiatan parenting untuk meningkatkan disiplin anak usia dini berpengaruh terhadap orang tua, 3. Untuk Mendeskripsikan hasil penyelenggaraan kegiatan parenting untuk meningkatkan disiplin anak usia dini. Dalam penelitian ini akan menggunakan beberapa metode. Adapun pendekatan penelitiannya menggunakan penelitian deskriptif kualitatif. Tekhnik penelitian yang digunakan oleh penulis dalam penelitian ini adalah: observasi, wawancara, dokumentasi dan studi literature, yang menjadi subyek dalam penelitian ini adalah orangtua anak usia dini di Kelompok Bermain Al-Aqwam Kecamatan Pameungpeuk. Hasil penelitian ini merujuk bahwa tingkat kemampuan disiplin anak masih kurang sebelum dilaksanakan kegiatan meningkatkan disiplin anak usia dini melalui kegiatan parenting, tetapi sesudah dilaksanakannya kegiatan tersebut sudah terlihat ada peningkatan. Hasil penelitian ini sudah mencapai indikator yang diharapkan dengan Meningkatkan Disiplin Anak Usia Dini Melalui Kegiatan Parenting di Kober Al- Aqwam Kecamatan Pameungpeuk.
\end{abstract}

Kata kunci : Parenting, Anak Usia Dini, Kedisiplinan

\section{PENDAHULUAN}

Salah satu amanat leluhur yang tercantum dalam UUD 1945 adalah "mencerdaskan kehidupan bangsa." setiap anak manusia memiliki potensi/bakat kecerdasan dan merupakan tanggung jawab pendidik, baik orang tua maupun guru di lembaga pendidikan untuk memupuk dan mengembangkan potensi/bakat tersebut secara sistematis melalui kegiatan pendidikan.

Secara Filosofi Pendidikan adalah suatu upaya untuk membantu memanusiakan manusia, artinya melalui proses pendidikan diharapkan terlahir manusia-manusia yang lebih baik, dalam pengertian yang konkrit anak harus lebih baik dari pada orang tuanya. Atas dasar ini, disimpulkan bahwa untuk menciptakan generasi yang cerdas dan berkualitas, pendidikan harus dilakukan sejak dini dan satu-satunya cara untuk memulainya adalah dengan menyelenggarakan lembaga pendidikan anak usia dini atau disingkat dengan PAUD.

Pendidikan anak usia dini adalah jenjang pendidikan sebelum pendidikan dasar yang merupakan suatu upaya pembinaan yang ditujukan bagi anak sejak lahir sampai dengan usia enam tahun yang dilakukan secara menyeluruh, mencakup semua aspek 
perkembangan dengan memberikan stimulasi terhadap perkembangan jasmani dan rohani anak agar dapat tumbuh dan berkembang secara optimal.

Dalam undang-undang sisdiknas nomor 20 tahun 2003, peraturan pemerintah tentang pendidikan anak usia dini pasal 1 ayat 1, dinyatakan bahwa : "PendidikanAnak Usia Dini yang selanjutnya disebut PAUD adalah salah satu upaya pembinaan yang ditujukan kepada anak sejak lahir sampai berusia 6 tahun yang dilakukan melalui pemberian rangsangan pendidikan untuk membantu pertumbuhan dan perkembangan jasmani dan rohani agar anak memiliki Kesiapan dalam memasuki pendidikan lebih lanjut".

Adapun tujuan dari pendidikan anak usia dini adalah untuk membantu dan mengembangkan potensi yang ada pada diri anak. Dalam pendidikan anak usia dini terdapat aspek-aspek yang harus dikembangkan sebagai potensi atau bakat untuk kehidupannya mendatang.

Dalam kurikulum pendidikan anak usia dini yang berkaitan dengan pendidikan karakter adalah terletak pada perkembngan nilai kecerdasan sosial emosional. Spesifikasi Perkembangan kecerdasan sosio emosional yang menyebutkan bahwa tingkat percapaian perkembangan sosial emosional anak adalah mengenal tata krama dan sopan santun sesuai dengan nilai sosial budaya setempat dan memahami peraturan dan disiplin serta menunjukan rasa empati, Di harapkan anak sudah mampu memahami makna sebuah kedisiplinan yaitu dengan taat dan patuh terhadap aturan, namun pada kenyataannnya rentang usia 4-5 tahun anak-anak belum disiplin dan belum memahami arti disiplin.

Menurut Hurlock, 2010 : 38, yang dimaksud disiplin adalah prilaku seseorang yang belajar diri atau secara sukarela mengikuti seorang pemimpin, orang tua dan guru merupakan pemimpin, sedangkan anak merupkan murid yang belajar dari orang dewasa tentang hidup yang menuju kearah kehidupan yang berguna dan bahagia dimasa mendatang.Menurut Gunawan, 2008, 70, disiplin sekolah artinya setiap anak harus mengikuti aturan dan tata tertib sekolah seperti cara berpakaian yang rapih dan ketepatan waktu.

Menurut Suryadi, 2013 : 34, disiplin merupakan suatu system pengendalian yang diterapkan oleh pengendalian yang di terapkan oleh pendidik terhadap anak didik agar mereka dapat berfungsi di masyarakat, seperti yang dikatakan oleh Hadiyanto disiplin adalah suatu keadaan dimana sikap dan penampilan, seorang peserta didik sesuai dengan tatanan nilai, norma dan ketentuan-ketentuan yang berlaku disekolah dimana peserta didik berada.

Jadi, secara sederhana kedisiplinan anak usia dini pada dasarnya adalah sikap taat dan patuh terhadap aturan yang berlaku,baik di rumah, sekolah, maupun masyarakat yang dilakukan oleh anak usia 0 - 6 tahun. Dengan demikian Sehingga dikatakan bahwa disiplin adalah proses bimbingan yang bertujuan menanamkan pola prilaku tertentu, kebiasaan-kebiasaan tertentu atau membentuk manusia dengan ciri-ciri tertentu, yang meningkatkan kualitas mental dan moral.

Dalam kontek pendidikan keluarga sebagai pendidikan informal akan terjadi dengan intensif dan bermakna dapat dipengaruhi oleh kemampuan orangtua dalam melaksanakan pola asuh sebagai transformasi awal dasar kehidupan. Kemampuan transformasi awal dasar kehidupan memerlukan sejumlah pengetahuan dan 
keterampilan usaha ini antara lain melalui parenting. Hal ini sejalan dengan apa yang di ungkapakan oleh Hoghughi, 2004 : 35

Parenting erat kaitannya dengan kemampuan suatu keluarga/rumah tangga dan komunitas dalam hal memberikan perhatian, waktu dan dukungan untuk memenuhi kebutuhan fisik, mental, dan sosial anak-anak yang sedang dalam masa pertumbuhan serta bagi anggota keluarga lainnya. Parenting mencakup berbagai aktifitas yang bertujuan agar anak dapat berkembang secara optimal dan dapat bertahan hidup dengan baik. Prinsip pengasuhan tidak menekankan pada siapa (pelaku) namun lebih menekankan pada aktifitas dari perkembangan dan pendidikan anak. Oleh karena itu, parenting meliputi pengasuhan fisik, pengasuhan emosi, dan pengasuhan sosial (Hoghughi, Parenting, 2004 : 35).

Peran keluarga dalam pendidikan anak sangatlah besar, terutama pada jalur pendidikan informal.anak lebih banyak menghabiskan waktunya di rumah dari pdada di luar rumah sehingga di butuhkan pengawasan serta perhatian lebih dari orang tua, memiliki peran yang sangat besar di dalam hal menentukan karakter dan memeksimalkan kecerdasan anak.

Pada saat sekarang yang terjadi kenyataannya adalah berkurangnya perhatian kepada anak di karenakan orang tuanya bekerja, hal tersebut mengakibatkan terbatasnya hubungan interaksi orang tua dengan anaknya, anak-anak kurang mendapatkan perhatian dari kedua orang tuanya di karenakan keduanya sama-sama sibuk dengan pekerjaannya masing-masing.sedangkan pada usia ini anak sangat membutuhkan perhatian lebih dari orang tuanya terutama untuk perkembangan kepribadiannya.

Hal tersebut dikarenakan perkembangan dan pertumbuhan anak yang harus berkembang dengan sehat dan memperoleh dukungan positif akan menjadi landasan yang kuat bagi perkembangan anak tersebut dikemudian hari, peneliti merasa tertarik untuk melakukan penelitian dengan mengambil judul "Meningkatkan Disiplin Anak Usia Dini Melalui Kegiatan Parenting di Kober Al- Aqwam Kecamatan Pameungpeuk."

\section{KAJIAN TEORI}

Banyak orang tua yang melaksanakan kepengasuhan dengan memanfaatkan naluri kepengasuhan alamiah, antara lain berupa kelemahlembutan cinta kasih. Sebagian lainnya, selain memanfaatkan naluri alami, melengkapinya dengan informasi-informasi yang dapat dipertanggungjawabkan secara alamiah, Dengan demikian, parenting adalah bagaimana cara mendidik orang tua terhadap anak baik secara langsung maupun tidak langsung. Parenting menyangkut semua perilaku orang tua sehari-hari baik yang berhubungan langsung dengan anak maupun tidak, yang dapat ditangkap maupun dilihat oleh anak-anaknya, dengan harapan apa yang diberikan kepada anak (pengasuhan) akan berdampak positif bagi kehidupannya terutama bagi agama, diri, bangsa, dan juga negaranya (Smart Parenting, George Prasetya Tembong, 3 : 2006).

Membuat anak curhat juga berarti membuat mereka merasa dekat dengan oragtua, jika anak akrab dengan orangtuanya dan tidak sungkan mengungkapkan perasaannya, maka lebih mudah bagi mereka untuk dimasuki pesan-pesan dari orangtuanya ( Ihsan Baihaqi dan Ibnu Bukhari, 2015 : 55).

Menurut Soelaeman (1985) menyatakan bahwa anak yang merasakan keamanan dan keterlindungan karena penghayatannya terhadap situasi dan kondisi, dan 
penghayatannya terhadap penghayatan fisik, akan melahirkan rasa memiliki dalam dirinya, hal itu terjadi karena dalam kehidupan keluarganya ada saling mengarahkan dan konsistensi dalam perilaku orang tua. Rasa itu mereka serap sebagai unsur yang menyatu dalam dunia kediriannya ( Kesatuan diri antara orangtua dan anak). Sejalan dengan itu Rutter (178, 108-110) menyetakan bahwa hubungan baik yang terjalin antara anak dengan orang tua dan antara ayah dan ibu dapat mencegah anak berperilaku agresif. Secara fenomenologis, hal ini menunjukkan bahwa situasi dan kondisi keluarga yang positif, yanh diciptakan oleh orang tua, dapat membuat anak untuk memiliki dan mengembangkan perilaku taat moral, yang bisa menjadi benteng bagi dirinya untuk tidak berperilaku agresif atau tidak berdisiplin diri. (Pola Asuh Orang Tua, Prof. Dr. Shochib, 104:2010).

\section{METODE PENELITIAN}

Metode penelitian yang digunakan adalah metode deskriptif kualitatif. Untuk memberikan kejelasan data, teknik pengumpulan data yang digunakan oleh peneliti dalam penelitian ini antara lain melalui: observasi, wawancara, studi dokumentasi dan studi kepustakaan.Dalam penelitian kualitatif data dikumpulkan oleh peneliti dengan memasuki lapangan agar data yang diperoleh lebih terinci menurut keinginan peneliti. Kegiatan ini sesuai dengan tujuan penelitian adalah untuk membuat deskripsi, gambaran atau lukisan secara sistematis, faktual dan akurat mengenai fakta-fakta, serta hubungan antara gejala/kejadian yang diselidiki.

\section{a. Observasi}

Adalah upaya aktif dalam pengumpulan data dengan berbuat sesuatu dan terlibat secara aktif didalamnya. Observasi digunakan untuk mendapatkan data yang lebih mendalam tentang parenting sebagai pendidikan kecakapan keorangtuaan dalam meningkatkan tumbuh kembang anak usia dini.

\section{b. Wawancara}

Dapat dipandang sebagai teknik pengumpulan data dengan cara tanya jawab. Wawancara dilakukan oleh peneliti dengan subjek utama yaitu orang tua peserta didik dan guru. Untuk mencari data bagaimana penelitian dilakukan dan bagaimana orangtua melaksanakan mengaplikasikan penerapan dalam pola asuh dalam keluarga. Wawancara di lakukan kepada orangtua, pedoman wawancara terlampir.

\section{c. Dokumentasi}

Dilakukan untuk memperoleh data yang bersifat administratif dan data kegiatankegiatan yang terdokumentasi. Menurut Nasution (2002), dalam penelitian kualitatif, dokumen termasuk sumber non human resources yang dapat dimanfaatkan karena memberikan beberapa keuntungan, yaitu bahannya telah ada, tersedia, siap pakai dan menggunakan bahan ini tidak menggunakan biaya.

\section{d. Studi Kepustakaan}

Dipergunakan untuk mendapatkan di jadikan pesan analisis data dan merupakan hasil penelitian sesuai dengan literature ilmiah, konsep-konsep tertulis untuk sebagai pedoman dan dasar dalam pengumpulan data. 


\section{HASIL DAN PEMBAHASAN}

Hasil penelitian disimpulkan sebagai berikut. Pertama, rancangan program parenting pada PAUD disusun melalui proses sebagai berikut: (1) Lembaga menyusun program parenting; (2) wali murid merancang program yang relevan dengan program lembaga, dan (3) merumuskan dan menetapkan program parenting sebagai program kerja tahunan komite sekolah. Kedua, implementasi program paren-ting pada PAUD meliputi kegiatan, sebagai berikut:(1) pertemuan formal Pra-pembelajaran anak di kelas, pertengahan dan akhir semester pertama, awal dan akhir semester kedua, dan komitmen bersama membantu pertumbuhan dan perkembangan anak, (2) pembinaan kemampuan dan keterampilan orangtua melalui kegiatan seminar, pelatihan, forum diskusi, dan membuat Alat Peraga Edukasi (APE), (3) Pendampingan anak oleh orangtua di dalam dan di luar kelas, seperti game, lomba, outbound, moving home, kunjungan ke rumah atau ke instansi-instansi pemerintah, dan (4) Kegiatan konsultasi dan keagamaan rutin mingguan. Ketiga, evaluasi program parenting pada PAUD dilakukan dengan cara, sebagai berikut: (1) menilai perubahan sikap dan komunikasi yang bersahaja antara orangtua dengan anaknya, (2) keaktifan orangtua dalam kegiatan parenting, (3) penilaian perkembangan mingguan anak, dan (4) pertanggungjawaban kegiatan parenting oleh pengurus komite sekolah secara lisan dan tertulis kepada wali murid dan lembaga.

\section{KESIMPULAN}

Berdasarkan hasil analisis penelitian dan pembahasan yang telah peneliti laksanakan pada Al-AQWAM Kecamatan Pameungpeuk, dapat disimpulkan sebagai berikut : Implementasi parenting dalam rangka meningkatkan disiplin anak usia dini yang dilaksanakan PAUD Al-AQWAM adalah untuk mengetahui sejauh mana pendidikan orangtua dalam pengasuhan terhadap anaknya, baik pengasuhan fisik, emosi dan sosial yang dilakukan oleh orangtua murid. Penerapan Parenting di KOBER bertujuan untuk memenuhi dan mengadakan kegiatan konsultasi dengan orangtua. Peningkatan kualitas pembelajaran di KOBER Al-AQWAM yang sesuai dengan perkembangan anak adalah meningkatkan kedisipilinan anak mengkuti proses belajar, bermain dan bernyanyi, berorientasi perkembangan anak usia dini, meningkatkan kecakapan bersosialisasi, memberikan pembelajaran benda konkrit dan dukungan dari orangtua.

\section{DAFTAR PUSTAKA}

Akhyadi, A. S., \& Mulyono, D. (2018). PROGRAM PARENTING DALAM MENINGKATKAN KUALITAS PENDIDIKAN KELUARGA. ABDIMAS SILIWANGI, 1(1), 1-8.

George Prasetya Tembong. (2006). Smart Parent. Jakarta. PT. Gramedia

Hoghughi. (2004. Pendidikan dalam Keluarga. Bandung. Tarsito

Hurlock, (2010). Meningkatkan Disiplin Anak Usia Dini. Jakarta. PT. Gramedia

Iksan Baihaqi dan Ibnu Bukhari (2013). Anak Usia Dini. Jakarta. Grasindo

Rutter. (2001). Pendidikan Keluarga. Bandung. Mandar Maju.

Shochib. (2010). Pola Asuh Orangtua. Jakarta. Rineka Cipta.

Soelaeman. (1994 ). Pendidikan Anak Usia Dini. Bandung. Remaja Rosdakarya 
Suryadi, (2013). Kedisipilan Anak Usia Dini. Bandung. Falah Production 